\title{
Possibilities Forage Legume Seed Production in Turkey
}

\author{
Aybegün Ton*, Adem Emin Anlarsal \\ Field Crop Department, Agricultural Faculty, Cukurova University, Turkey
}

Copyright $\subset 2017$ by authors, all rights reserved. Authors agree that this article remains permanently open access under the terms of the Creative Commons Attribution License 4.0 International License

\begin{abstract}
There are suitable ecological regions of Turkey for seed production of legume forage crops. At the stage of flowering and seed maturation low humidity and high temperature can cause to reduction in seed yield. Ecological conditions of Central and Southern Anatolia are very favorable for seed production in legume forage crops. Alfalfa, common vetch, sainfoin are most important among the forage crops cultivated in Turkey. Some cultivars belonging to above the mentioned species have been developed in Turkey. High-quality seed is essential for good field stands. Seed crops should be produced taking into consideration with seed production rules. Control of seed quality in seed production must conform to statutes of National Certification Standard. High yields of good quality seed are obtained under good management such as sowing time and rate, irrigation, fertilizer, weed control, storage conditions isolation distance and certification rules.
\end{abstract}

Keywords Forage, Legume, Production, Seed

\section{Introduction}

Legume forage crops are producing a wide area in the world. Forage legumes have high protein ratio, amino acids, minerals and vitamins, and it is used as hay, green forage, silage and grain fodder in the world. Forage legume is also attributed to the soil for providing nitrogen and organic matter and it is very important in crop ration [1-2]. Seeds are the most important input in crop production and use of quality seeds are prerequisite for good forage production. Successful forage legume seed production includes cultural management, adequate pollination, suitable varieties, specific soil and climatic conditions. [3-4].

In Turkey total area of forage crops increased recently. Legume forage crops such as alfalfa, vetch and sainfoin are most important among the forage crops cultivated in Turkey. Total areas used for forage crops production are 1.764.000 ha in Turkey. Area of legume forage crops covers about $76.0 \%$ of forages cultivations [5]. Support for use of certified seed has been carried out in Turkey in recent years. Mostly public sectors and private seed companies produce the certified forage legume crop seeds. Use of certified seeds and growing techniques for forage crop production applied by farmer is deficient.

They haven't got custom of using variety and certified seed is rather expensive. The farmers are using the seeds that they produce on their own. Profitability in seed production of the forage legume is low, because of the fact that the use of certified seeds is little.

However, Turkey has a great forage legume seeds production for ecological conditions. These conditions can be evaluated for quality seeds production. Certified seed of varieties with high genetic potential should be used in suitable climate conditions and appropriate farming techniques in agricultural production. High-quality seed crops should be produced taking in to consideration with seed production rules. The factors affecting the seed quality are varietal purity, good germination, good seedling vigor, free from disease infections, free from weed seed, right moisture percentage, good level of physical purity, good maturity period and uniform seed. The farmers should be encouraged and informed about the use of certified forage seed. Certified seed of many legume forage crops needed by farmers can be successfully produced in Turkey.

It was discussed possibilities and growing techniques for quality seed production of forage legume crops in Turkey in this paper. So, forage legume seed production will be improved in Turkey.

\section{The Seed Production of Forage Legumes}

In Turkey, seed production of legume forage crop has varied year after year due to changing area planted. Support for use of certified forage crop seeds has carried out and seed requirement increased in Turkey recently. Generally in the last five years certified seed production has increased in alfalfa and vetch while it has decreased in sainfoin [6]. Demand/supply rate for seed in alfalfa is higher than other legume forages. Some cultivars of legume forage crop have developed in Turkey and their seeds have been produced by private and mostly public sector [7]. However, alfalfa seed production is higher than sainfoin and vetch seed production 
in private sector. The farmers haven't got custom of variety using at adequate level. The farmer should supply seed crop with suitable prices and through an easy way [8].

\section{Appropriate Regions for Forage Legumes Seed Production in Turkey}

There are good potential for ecological conditions to produce quality seed of legume forage crops in Turkey. Regions which are suitable for climate and soil conditions for seed production of forage crops should be chosen. Climate conditions during the stage of flowering and seed maturation for high seed yield in legume forage crops are very important. At this stage, low humidity and high temperature can cause to reduction in seed yield. [9-10].

For these reason coastal regions of Turkey are not suitable for forage legume seed production, but ecological condition of Central and Southern Anatolia is very favorable for seed production.

Soil demand of different legume forage crops is variable for seed production. Seed production should be made generally in medium fertile soil. Because in fertile soil, vegetative growth of forage crops is good, but flowering and seed set delay. As a result, seed yield decreases.

\section{Agricultural Activities in Seed Production of Legume Forage Crops}

\subsection{Variety}

In Turkey many cultivars of alfalfa and vetch with tolerance to the diseases and good fodder performance have been developed, but demand of farmer is little for certified seed. The farmers are using the seeds that they produce on their own. The seed crops should be produced taking into consideration with seed production rules. Some farmers are using mixed seed provided either from different sources or from some imported seed crop especially alfalfa. In recent year, certified seed production of cultivars developed in Turkey has increased, but it is not adequate. On the other hand, cultivars of other legume forage crops such as sainfoin, clover, rough pea were developed in few numbers. However it is important to develop new varieties for different regions of Turkey.

\subsection{Cultural Practices}

High yield of good quality seeds is obtained only under good management. Sowing times of forage and seed production are almost similar to each other while their harvest times are different. Seeding should be made with drill. Row spacing for seed production is different from forage production. Wide row spacing and low quantity of seed should be applied for high yield in seed production.
Row spacing of alfalfa varies from 75 to $100 \mathrm{~cm}$. On the other hand seed rate varies between 5 and $10 \mathrm{~kg} \mathrm{ha}^{-1}$ [3]. Seed rate and row spacing of vetch and change from 50 to $60 \mathrm{~cm}$ and between 60 and $80 \mathrm{~kg} \mathrm{ha}^{-1}$ respectively [11]. Row spacing of sainfoin varies from $25-50 \mathrm{~cm}$ [12]. Seed rate of sainfoin changes between $80-100 \mathrm{~kg} \mathrm{ha}^{-1}$.

In seed crop fertilization, all factors affecting their growth should be considered. Legume forage crops for seed production under the irrigation conditions need 8-10 $\mathrm{kg} \mathrm{ha}^{-1}$ of phosphorus, but phosphorus requirement for perennial plant such as alfalfa is determined taking account of stand longevity and it should be given into the soil at once.

Like all other crops, forage crops must compete with weeds; weed control should be carried out especially to their most successful production [13]. In the seed field, weed control should be made through the cultural and chemical or mechanical methods [14].

Forage crops irrigation depend on seed soil texture, soil depth, soil properties, rainfall, evaporation and plant root depth. Seed yield of legume forage crops under irrigation conditions will increases. Water requirement at the stage of flowering and seed set stage of legume forage seed is relatively much. Perennial legume forage crops such as alfalfa should be irrigated before flowering stage.

\subsection{Diseases and Insect Control}

Seed quality is one of the most important features of quality for seed production. Certified legume forage seed should not be contaminated with insect and diseases. Legume forage seeds are susceptible to many of diseases and insects. Duration of seed production is longer than forage crops. So, seed crops are affected from disease and insect. They are generally controlled by chemically. Also certified seeds of cultivars developed resistant to diseases and insect should be produced.

\subsection{Mechanization}

In legume forage seed production especially sowing, harvesting, seed cleaning and storage should take the advantage of developing mechanization. If seeding is made with the drill, use of seed is reduced. Machine harvest reduces seed losses. Some of the legume forage seeds don't not mature at the same time. In this case harvesting with machine is difficult. At the same time maturing legume forage crops can be harvested with combine machine. If pods are dry, but stems are still green, chemical desiccant and defoliant should be used before harvesting $[3,14]$. Harvesting should be made in early in the morning. Otherwise, seed losses may occur extensively.

Both the public and private sector should organize some educational films about planting, irrigation, and in especially about harvesting for farmers who produce seed and they should show some practical ways to these farmers [15]. 


\subsection{Storage}

Several factors may affect the longevity of seeds stored in natural or controlled environments. These factors are moisture, temperature, gaseous exchange, seed coat character, maturity, micro flora and insect infestation. Optimum moisture content of seed crop for storage should be $10 \%$ [16]. Each reduction of $5^{\circ} \mathrm{C}$ between $50^{\circ} \mathrm{C}$ and $0^{\circ} \mathrm{C}$ increases double the storage life [17].

\subsection{Isolation Distance}

Isolation distance is very important to obtain pure variety. So, the different varieties of the same species must be sown at certain distance to prevent contamination among varieties. Seed production of some legume forage crop depends on pollination by insects. For example; alfalfa and sainfoin flowers are attractive to bees with their nectar and pollens. Isolation distance is more important for cross-pollinated legume forage crops. Isolation distance in certified seed production must be $200 \mathrm{~m}$ for alfalfa, vetch, sainfoin etc. [18].

Table 1. Isolation Distance of Some Important Legume Forage Crops

\begin{tabular}{|c|c|c|}
\hline Species & Original & Certified \\
\hline Alfalfa, Vetch, Sainfoin & $400 \mathrm{~m}$ & $200 \mathrm{~m}$ \\
\hline
\end{tabular}

\subsection{Certification}

Laboratory Standards of Some Important Legume Forage Crops were given in Table 2 [18].
In the fields which seed of alfalfa, sainfoin and vetch are the produced, the different varieties of same species should not be planted before 3 years on the same field to prevent contamination from the previous crop. In particular, the field must be checked during time of the blooming. High-quality seed is essential for good field stand under good or poor field conditions [16]. Also, seed fields should be cleansed from different varieties and other crop plants. The varietal purity, percentage of germination and moisture are determined in the seed samples taken from cleaned seed crop for laboratory analysis.

\section{Conclusions}

Legume forage crops such as alfalfa, vetch and sainfoin are most important among the forage crops cultivated in Turkey. There are good potential for ecological conditions to high amount and quality seed production of legume forage crops in Turkey. High yields of good quality seed are obtained under good management such as sowing time and rate, irrigation, fertilizer, weed control, isolation distance and certification rules. Seed production and use of certified legume forage crops have increased in recent years. Certified alfalfa and vetch seed production and are higher than sainfoin. Generally, the farmers are using the seeds that they produce on their own. Some farmers use imported seed. Certified seed production in legume forage crops and their use by farmers should be increased. Widespread of using certified seed will increase profitability and quality of forage crops production.

Table 2. Laboratory Standards of Some Important Legume Forage Crops

\begin{tabular}{|c|c|c|c|c|c|c|}
\hline \multirow{2}{*}{ Species } & \multirow{2}{*}{$\begin{array}{l}\text { Germination (At } \\
\text { Least } \% \text { ) }\end{array}$} & \multirow{2}{*}{$\begin{array}{l}\text { Pure Seed (At } \\
\text { Least \%) }\end{array}$} & \multirow{2}{*}{$\begin{array}{c}\text { Inert Matter } \\
\text { (Maximum \%) }\end{array}$} & \multicolumn{2}{|c|}{$\begin{array}{l}\text { Other Species and Varieties } \\
\text { (Maximum \%) }\end{array}$} & \multirow{2}{*}{$\begin{array}{c}\text { Total Weed Seed } \\
\text { Rates } \\
\text { (Maximum \%) }\end{array}$} \\
\hline & & & & Certified 1 & $\begin{array}{l}\text { Certified } \\
\text { II-III-IV }\end{array}$ & \\
\hline Alfalfa & 85 & 98 & 2 & - & - & 0,5 \\
\hline Vetch & 85 & 98 & 2 & 0,5 & 0,8 & 0,5 \\
\hline Sainfoin & 75 & 95 & 5 & - & - & 0,5 \\
\hline
\end{tabular}




\section{REFERENCES}

[1] Greenland DJ 1975.Contribution of Microorganisms to the Nitrogen Status of Tropical Soils. In: A. Ayanaba, PJ. Dart. (Eds.). Biological Nitrogen Fixation in Farming Systems of the Tropics. International Institute of Tropical Agriculture, Nigeria, 13-25.

[2] Fairey DT. 1987. Growing forage legumes for seed. Agriculture Canada Research. Station, Agdex120/15-1, Beaverlodge, Alberta, p: 1-3

[3] Pedersen, M.W., Bohart, G.E., Marble V.I., Klostermeyer E.C., 1972. Seed Production Practices. In: C.H. Hanson (Ed.) Alfalfa Sci. And Tech. ASA Publ., p: 689-720.

[4] Haddad, NI., 1996. Seed Production of Grain Legumes.. In: AJG. Van Gastel, MA. Pagnotta, E. Porceddu. (Eds.). Seed and Technology. ICARDA, 195-200.

[5] TÜİK (2015):Turkish statistical institute. http:/www.tuik.gov.tr.

[6] Anonymous (2015a). Seed statistical. Republic of Turkey ministry of food, agriculture and livestock. www.tarım.gov.tr.

[7] TİGEM (2013): Tohumculuk sektör raporu. Tarım işletmeleri Genel Müdürlüğü, Ankara. 42 s.

[8] Cakal, M., (2013): TRA1 Bölgesi Tohumculuk Raporu. KUDAKA Araştırma ve Planlama Birimi, 19 s.

[9] Bula RJ, Massengale MA, 1972. Environmental Physiology. In: H. D., Hughes, M. E., Heath, D. S. Metcalfe (Eds). Forages.

The Lowa State College Press. Ames, Iowa., p: 167-184.

[10] Seymour M. Siddque K, Prichard L, Brandon N, Reithmuller G, Latham L. 2003. Common vetch production technology. Department of agriculture, Western Australia of government, Bulletin 4578, 38p.

[11] Elçi, Ş, 2005. Baklagil ve Buğdaygil Yembitkileri. Tarım ve Köy İşleri Bakanlığı, Ankara. 486s.

[12] Tan, M., Sancak, C., 2009. Korunga (Onobrychis vicifolia Scop.) Bölüm 10 (Editör: Avcıŏlu R., Hatipoğlu R., Karadağ Y.) Tarım ve Köyişleri Bakanlığı Tarımsal Üretim ve Geliştirme Müdürlüğü. İzmir. s: 337-352.

[13] Willard, C. J., 1952. Weed Control in Forages. In: H. D., Hughes, M. E., Heath, D. S. Metcalfe (Eds). Forages. The Lowa State College Press. Ames, Iowa., p: 461-465.

[14] Açıkgöz, E., (2001): Yem Bitkileri. Uludağ Üniversitesi Güçlendirme Vakfi Yayın No: 182. s:584. Bursa.

[15] Bilgili, U., Hakyemez B.H., Avcıŏglu R., (2009): Yembitkileri Tohumculuğu. (Editör: Avcıoğlu R., Hatipoğlu R., Karadağ Y.) Tarım ve Köyişleri Bakanlığı Tarımsal Üretim ve Geliştirme Müdürlüğü. İzmir. s: 187-213.

[16] Gunn, C.R., (1972): Seed Characteristics. In: C.H. Hanson (Ed.) Alfalfa Sci. And Tech. ASA Publ., p: 677-687.

[17] Harrington, J.F., (1970): Seed and Pollen Storage for Conservation of Plant gene resources In: Frankel, O.H. and Bennet E.(eds). Genetic Research in Plants Exploration and Conservation Blackwell Scientific. Oxford, UK, pp. 501-521.

[18] Anonymous (2015b): Variety Registration and Seed Certification Centre Republic of Turkey Ministry of Food, Agriculture and Livestock. www.tarim.gov.tr. 